\title{
Seasonal weather effects on the common eider, a subarctic capital breeder, in Iceland over 55 years
}

\author{
Jón Einar Jónsson ${ }^{1, *}$, Arnthor Gardarsson ${ }^{2}$, Jennifer A. Gill ${ }^{3}$, Aevar Petersen ${ }^{4}$, \\ Tómas Grétar Gunnarsson ${ }^{1}$
}

\author{
${ }^{1}$ University of Iceland, Snæfellsnes Research Centre, Hafnargata 3, 340 Stykkishólmur, Iceland \\ ${ }^{2}$ Institute of Biology, University of Iceland, Sturlugata 7, 101 Reykjavík, Iceland \\ ${ }^{3}$ School of Biological Sciences, University of East Anglia, Norwich, Norfolk NR4 7TJ, UK \\ ${ }^{4}$ Icelandic Institute of Natural History, Hlemmur 3, 105 Reykjavík, Iceland
}

\begin{abstract}
Changes in bird populations and their phenology (i.e. timing of nesting and migration) are increasingly linked to global climatic changes, particularly at temperate and Arctic latitudes. These patterns arise from local- and regional-scale effects of weather on demography but long-term time-series data necessary to explore these relationships are rarely available. Colonies of the common eider Somateria mollissima are often monitored annually for nest-down harvesting. We use long-term data from 2 nesting colonies in northwest Iceland (Bíldsey, Breiðafjörður: 29 yr and Lækur, Dýrafjörður: 55 yr) to examine the effects of weather conditions in each season on breeding numbers, arrival dates and clutch sizes. Numbers of nests in Bíldsey increased following warm, wet winters and first nests were produced later following windy and wet winters at Lækur. In spring, windy conditions tended to be followed by earlier female arrivals at Bíldsey. Warm, wet springs were positively correlated with larger clutch sizes at Lækur, and clutch sizes at Lækur decreased following especially wet and warm autumns. The overall population trends vary among sites and are likely to be influenced by both climatic and management conditions. These findings indicate that the effects of global climatic changes will depend on the details of changes in local weather conditions within each season. The strong effects on nesting dates and clutch sizes suggest that accumulation of body reserves, which sustain females during incubation and into brood rearing, is a key mechanism that could determine how altered distribution and frequencies of depressions within each season will affect future numbers of this species.
\end{abstract}

KEY WORDS: Climate $\cdot$ Phenology $\cdot$ Temperature $\cdot$ Winter harshness $\cdot$ Breeding $\cdot$ Arctic $\cdot$ Waterfowl $\cdot$ Capital breeder

Resale or republication not permitted without written consent of the publisher

\section{INTRODUCTION}

Weather impacts can occur at local or regional scales (Newton 2007, Robinson et al. 2007). Over the coming decades, global climatic change is predicted to increase the Earth's mean annual temperature by 2 to $4^{\circ} \mathrm{C}$ and to redistribute severe weather events, which will affect animal populations at both regional and global scales (IPCC 2001, Parmesan \& Yohe 2003, Thomas et al. 2004, Jonzen et al. 2006). Arctic and subarctic species are particularly vulnerable because climate changes are predicted to occur disproportionately at the highest latitudes (Serreze et al. 2000,
Lehikoinen et al. 2006). Improved understanding of relationships between weather events and demography is essential for the construction of models of population responses to global changes (Robinson et al. 2007).

The phenology of spring migrating birds is often dependent on the severity of the preceding winter and the current spring (Lehikoinen et al. 2006, Solonen 2008). Timing of arrival on the breeding grounds and of nesting, as well as subsequent hatching and brood rearing are key variables in the breeding success of migratory species (Prop et al. 2003, Durant et al. 2004, Frederiksen et al. 2004, Gunnarsson et al. 2004). At 
Arctic latitudes $\left(66^{\circ} \mathrm{N}\right.$ and higher), the short summer predisposes birds to complete breeding in a particularly short time (Poussart et al. 2000). A number of studies have shown how initiation of breeding is related to trends in climatic change, particularly through earlier spring migration and subsequent initiation of breeding (Durant et al. 2004, Frederiksen et al. 2004, Sparks et al. 2005, Jonzen et al. 2006, see also Robinson et al. 2007 and citations therein).

Early nesters are generally individuals in relatively good body condition, which often consequently lay the largest clutches and attain the highest breeding success (Erikstad et al. 1993, Arnold et al. 2004, Bêty et al. 2004). Clutch size correlates with body condition in Arctic-breeding geese (genera Anser, Chen and Branta) and in ducks such as the common eider Somateria mollissima (Ankney \& MacInnes 1978, Erikstad et al. 1993, Öst et al. 2008). Many birds exhibit a seasonal decline in clutch size (Arnold et al. 2004) and chick survival may decrease with advanced hatching date (Traylor \& Alisauskas 2006). Moreover, advances in nest initiation date in response to climatic changes can be detrimental if they cause breeding to be mistimed with peak food abundance (Both et al. 2006). In waterfowl, females deposit endogenous reserves for breeding in the preceding winter (Parker \& Holm 1990, Meijer \& Drent 1999). Starvation and nest abandonment are common in late spring when females can be in poor body condition and nest initiation is delayed (Ankney \& MacInnes 1978, Alisauskas 2002). Poor breeding condition of adults may also lead to poor immune defense of the resulting offspring (Lehikoinen et al. 2006).

Female common eiders rely heavily on endogenous body reserves for the incubation period, during which they do not feed at all (Parker \& Holm 1990, Meijer \& Drent 1999). This part of the annual cycle is very demanding for female waterfowl such that they may abandon breeding altogether in years of poor body condition (cf. Ankney \& MacInnes 1978, Coulson 1984, Anteau \& Afton 2006, Arzel et al. 2006). The common eider has a circumpolar range, breeding from 40 to $80^{\circ} \mathrm{N}$, which contributes greatly to the variation in climate and length of breeding season experienced by individuals in different parts of the range (Bustnes et al. 2002). Like other species of the genus Somateria, the common eider is considered hardy and adept at surviving harsh Arctic conditions (Goudie et al. 2000, Systad et al. 2000). Iceland-breeding common eiders experience relatively pronounced weather fluctuations. Like other hardy, short-distance migrants, they may respond strongly to climate change (Lehikoinen et al. 2006, Novoa et al. 2008), particularly because the females use endogenous reserves for incubation (i.e. they are capital breeders; Meijer \& Drent 1999).
The common eider is the most abundant waterfowl species in Iceland, with an estimated quarter of a million pairs (Asbirk et al. 1997). They are resident in Iceland, where they breed on the coast and form large flocks during the non-breeding period. The common eider has been completely protected from hunting in Iceland since 1850 and from egg collection by the public since 1787 because of the economic importance of down collection, but the species is legal quarry in other parts of their distribution range (Goudie et al. 2000, Petersen \& Skírnisson 2001).

We used data from 2 separate nesting colonies with long-term counts of numbers and timing of arrival of breeding females to examine if (1) local weather conditions in each season of the year prior to breeding influence the numbers of breeding birds, arrival dates and clutch sizes; and (2) large-scale indices of climatic and oceanic conditions are related to breeding numbers ( no. of nests), arrival dates and clutch sizes.

1.1. Effects of weather in the preceding summer (June-September). Unfavourable weather in summer, when ducklings are very small and vulnerable to weather conditions, is likely to have negative effects on duckling survival (Sæther et al. 2004, Traylor \& Alisauskas 2006). Favourable conditions in breeding grounds in a given year are also positively correlated with return rates of adults the following year (Gardarsson \& Einarsson 1997). Hence, we examined if weather in the preceding summer was correlated with arrival at the colony, breeding numbers and clutch size of common eider females.

1.2. Effects of weather in the preceding autumn (October-November). Waterfowl are unusual in that they form pair bonds during autumn or winter, presumably to enhance social status (McKinney 1986). Pairs dominate lone birds, and paired females are able to forage more effectively than unpaired ones (Ashcroft 1976, Hepp 1984). Common eiders begin pair formation in September, with $60 \%$ of all females being paired by November and the remaining females not forming pairs until spring (Spurr \& Milne 1976). Thus, weather during autumn may influence the initial stage of pair formation, particularly if common eiders suffer energy deficits due to unfavourable weather such as frosts or windy conditions. Ducks form pair bonds later in cooler climates (Jónsson \& Gardarsson 2001) and delay pair formation in harsh winters (Raitasuo 1963). Thus, we examined if weather in the preceding autumn was correlated with breeding numbers, arrival, and clutch size.

1.3. Effects of weather in winter (December-March). Diving ducks maintain endogenous reserves, which may sometimes be needed to survive the winter (Lovvorn 1994). Decreased air and sea temperatures and increased wind and wave action during winter all 
entail increased energy costs (Lovvorn 1994, Systad et al. 2000). Eider males decrease time spent in displays during mid-winter but resume displays as daylength increases again in spring (Systad et al. 2000). Severe weather during the coldest months of the year can directly increase adult mortality and affect population size (Sæther et al. 2004). Low body mass in winter delays the onset of pair formation (Pattenden \& Boag 1989) but the enhanced social status of paired females is critical for deposition of endogenous reserves (Ashcroft 1976, Hepp 1984). Thus, we examined if weather in the preceding winter was correlated with breeding numbers, arrival, and clutch size.

1.4. Effects of weather in spring (April-May). In Iceland, most common eiders nest in May, although a few individuals may initiate nesting as early as April or as late as June (Petersen \& Skírnisson 2001). Weather conditions in late winter and early spring are likely to have the most pronounced effects on this part of the annual cycle (cf. Newton 2006, Drent et al. 2006), particularly for females whose body mass is low at the beginning of incubation (cf. Parker \& Holm 1990). We examined if weather in spring was correlated with breeding numbers, arrival, and clutch size.

1.5. Density-dependence effects. We tested for density-dependence effects on arrival dates by correlating arrival with breeding numbers. It was important to consider trends in our data because common eider farmers often attempt to increase the number of nests in their colonies to increase eider down yield (Jónsson 2001); thus, increases in local breeding numbers probably represent such efforts as well as overall population trends.

\section{METHODS}

The common eider remains husbanded for eiderdown in Iceland (Jónsson 2001, Bédard et al. 2008), in contrast to the diminishing eider husbandry in other parts of the species range (Olsson \& Thorvaldsen 2006). We obtained nest counts from eider farmers in northwest Iceland: (1) on the island of Bíldsey $\left(65^{\circ} 07^{\prime} \mathrm{N}\right.$, $22^{\circ} 43^{\prime} \mathrm{W}$ ), where nests were counted yearly from 1978-2009; and (2) Lækur $\left(65^{\circ} 55^{\prime} \mathrm{N}\right.$, $\left.23^{\circ} 34^{\prime} \mathrm{W}\right)$, where nests were counted yearly from 1953-2007. We selected these colonies because at Bíldsey, nests were counted during 2 to 5 visits some time between 8 May and 29 June each year, and the farmer at Lækur recorded the date when the first nest was found (hereafter first nest date). This allowed analysis of arrival dates at each colony as well as changes in the numbers of breeding females.
Bíldsey is a low, grass-covered island of 211 ha in the Breiðafjörður Bay, and is located $5 \mathrm{~km}$ north of the town of Stykkishólmur. The island is one of over 3000 islands in the Bay and is uninhabited by humans throughout the year. Breiðafjörður contains the bulk of all rockweed beds in Iceland and at least $20 \%$ of the Icelandic common eider breeding population (Stefánsson et al. 2008). Intertidal rockweed (Ascophyllum spp.) beds are an important brood rearing habitat for common eider (Hamilton 2001) and they are widespread in Breiðafjörður Bay as are beds of the blue mussel Mytilus edulis, which is a primary food of adult common eiders (Skírnisson et al. 1996, Goudie et al. 2000).

Lækur is a farm inhabited throughout the year and the eider colony was established in the early 1950s by the use of nest shelters and predator control (Jónsson 2001). The area is characterised by narrow strips of agricultural lowlands ( $2-5 \mathrm{~km}$ wide) bordered by steep mountains surrounding fjords. Breeding numbers and first nest dates are available from 1953-2007 and mean clutch size was recorded from 1975 onwards. This allowed analysis of first nest dates and clutch sizes as well as changes in the numbers of breeding females.

2.1. Dependent variables. Our 2 time series differed in length as well as the variables measured (Table 1). For Bíldsey, we estimated arrival date each year by calculating the percentage of arrived birds at each count date, i.e. the number arrived divided by the last count (hereafter breeding numbers) for each year. We then performed linear and polynomial regressions for each year and used regression equations and visual inspection of trend lines to estimate the date when $50 \%$ of all females had arrived (hereafter arrival date). This calculated arrival date was our index of annual nest initiation for the Bíldsey colony. Arrival dates at Bíldsey in the years 1981, 1982, 1989 and 2005-2007 could not be estimated because the farmer visited the island only 1 to $2 \times$ in these years. Following Yaffee (2000) for treatment of missing values, we used the average arrival date $\left(=24.8 \mathrm{~d}_{i} 1 \mathrm{May}=1\right)$ to represent the missing arrival dates in the time-series analysis. There were no missing values for first nest dates at Lækur.

Table 1. Variables that were estimated at each of 2 common eider colonies in northwestern Iceland and series length at each colony. + variable was measured - variable was not available

\begin{tabular}{|c|c|c|c|c|c|}
\hline \multirow[t]{2}{*}{ Colony } & \multirow{2}{*}{$\begin{array}{l}\text { Series } \\
\text { length }\end{array}$} & \multicolumn{4}{|c|}{ Variables measured/estimated } \\
\hline & & $\begin{array}{l}\text { Breeding } \\
\text { numbers }\end{array}$ & $\begin{array}{c}\text { Arrival } \\
\text { date }\end{array}$ & $\begin{array}{c}\text { First nest } \\
\text { date }\end{array}$ & $\begin{array}{l}\text { Average } \\
\text { clutch size }\end{array}$ \\
\hline Bíldsey & $1978-2007$ & + & + & - & - \\
\hline Lækur & $1953-2007$ & + & - & + & $+{ }^{*}$ \\
\hline
\end{tabular}


2.2. Local weather conditions. We obtained climate data (temperature, air pressure, precipitation and wind speed) averaged into 4 seasons (JJAS = summer, $\mathrm{ON}=$ autumn, DJFM = winter and $\mathrm{AM}=$ spring) from the Icelandic Meteorological Office. Data are from the weather station in Stykkishólmur, which is the longestrunning weather station in Iceland (in operation since 1846). The weather in Stykkishólmur is representative of weather throughout Iceland, where fluctuations in temperature occur synchronously over the entire country (see Fig. 2 in Jónsson 2006).

2.3. Regional-scale climatic conditions. Climate change can be quantified on regional scales in addition to consideration of local effects; our interest was particularly on indices of winter severity (cf. Lehikoinen et al. 2006), especially the winter (December through March) North Atlantic Oscillation index (NAO), which is based on the difference of normalized sea level pressure between Lisbon, Portugal and Stykkishólmur, Iceland (Hurrell et al. 2001; www.cgd.ucar.edu/cas/ jhurrell/indices.html). Positive values of the index indicate stronger-than-average westerlies over the middle latitudes, and are also correlated with the frequency of warmer winters in west Europe. Therefore, we tested for correlations of the midwinter NAO index with breeding numbers and arrival dates. We also tested for a correlation between the midwinter NAO index and local weather indices (see 2.1.5) to evaluate the influence of the NAO on weather in Stykkishólmur.

2.4. Time-series analysis. We chose time-series models over regression models because (1) some of our series were visibly non-stationary or exhibited trends (Figs. 1 \& 2); (2) we doubted that weather and common eider breeding had a linear relationship over time, even if they were causally related; (3) the nature of the relationship between weather and eider breeding could change over time; and (4) other factors (such as food availability, predators, carrying capacity), which we could not include in our study, could explain some of the discrepancies in the relationships between weather and common eider breeding.

We used arithmetic moving average (ARIMA) models for our time-series analysis (Yaffee 2000). This methodology requires that input series have observations that are equally spaced over time (1 yr in our case) and possess at least weak stationarity, i.e. constant mean and variance over time (Yaffee 2000). We tested the data series for non-stationarity using the Dickey-Fuller test (PROC ARIMA; SAS Institute 2001). Non-stationary series were rendered stationary by differentiation, i.e. by subtracting the value for the current year from the value of the previous year, in the case of a single mean or deterministic trend. This method transforms variables to levels of changes to attain series stationarity. Also, we used residual analy- sis (PROC REG or PROC STANDARD; SAS Institute 2001) in the case of a significant, non-stochastic trend (Yaffee 2000, Brocklebank \& Dickey 2003). We then used transfer function models in PROC ARIMA (maximum likelihood estimation) and an accompanying regression analysis (PROC REG; SAS Institute 2001) to examine relationships between (1) arrival dates and breeding numbers; and (2) arrival dates and breeding numbers in the previous year. Then we tested for correlation of the midwinter NAO index with breeding numbers and arrival dates at both colonies and with clutch size at Lækur.

2.5. Analysis of weather relationships. Effects of local weather were explored by using a principal components analysis (PCA, PROC PRINCOMP; SAS Institute 2001) to reduce the number of weather variables within each season (4 variables and 4 seasons $=16$ ) that exhibited linear dependencies (see also Traylor \& Alisauskas 2006). Each colony was analyzed separately because (1) the time series differed in length; (2) different indices of arrival date were used at each colony; and (3) colonies differ in properties such as shelter, prevailing winds and (probably) in locations used as wintering grounds.

Principal components (PC) scores that explained $\geq 25 \%$ of the variation in the weather data were retained as explanatory variables in a backwards model selection in PROC ARIMA and PROC REG in SAS (SAS Institute 2001) to test our hypotheses about weather effects on breeding numbers and arrival dates of common eider. We used the Shapiro-Wilks test to assess normality of residuals of all regressions (PROC UNIVARIATE; SAS Institute 2001), and found all p-values to be $>0.05$. We visually inspected all significant relationships for influential outliers and re-ran analyses if 2 to 4 such values were detected to confirm the validity of relationships (Jónsson et al. 2006).

2.6. Series stationarity. At Bíldsey, all values presented in model selections are from PROC ARIMA. The Dickey-Fuller tests indicated non-stationarity for breeding numbers by rejecting the hypothesis of a single mean and barely failing to reject a trend (see Fig. 1). Stationarity was achieved for breeding numbers by detrending with residual analysis (hereafter residual breeding numbers) whereas the raw series was analyzed for arrival date. For arrival date (see Fig. 2), the Dickey-Fuller test failed to reject the hypothesis of more than one mean and the presence of a trend, indicating stationarity.

At Lækur, all values presented in model selections are from PROC ARIMA. The Dickey-Fuller tests indicated non-stationarity for breeding numbers (see also Fig. 1), first nest dates and average clutch sizes (see also Fig. 2). Thus, stationarity was achieved for breeding numbers by logarithmic transformation and then 

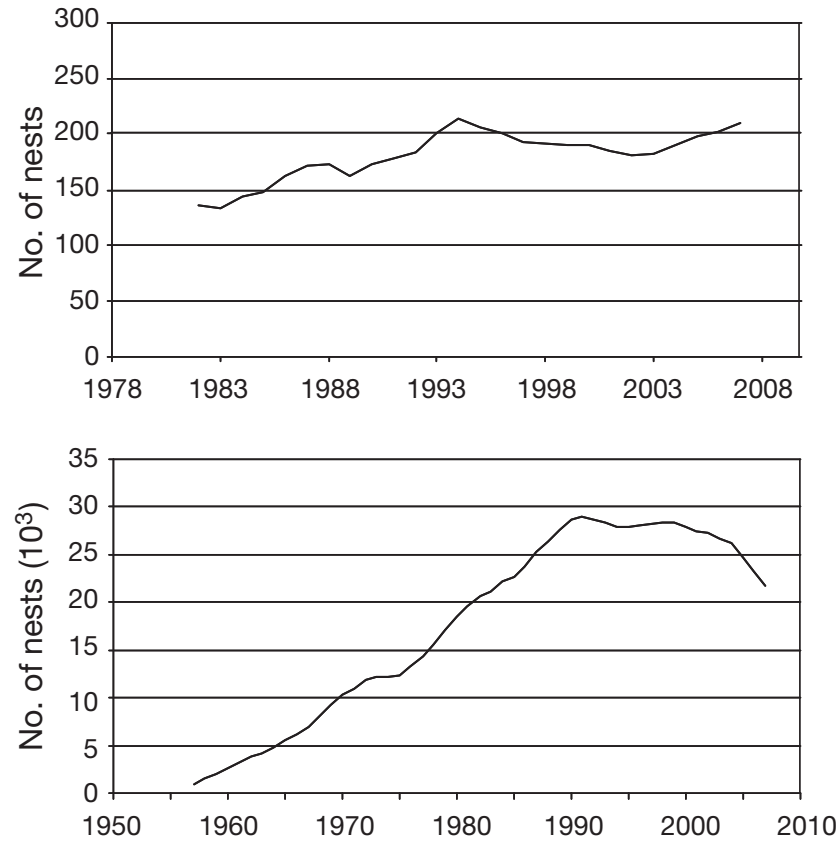

Fig. 1. Somateria mollissima. No. of common eider nests at Bíldsey (top) and Lækur (bottom) in northwest Iceland. Data are presented as 5 yr running means. Note different scales on both $x$ - and $y$-axes
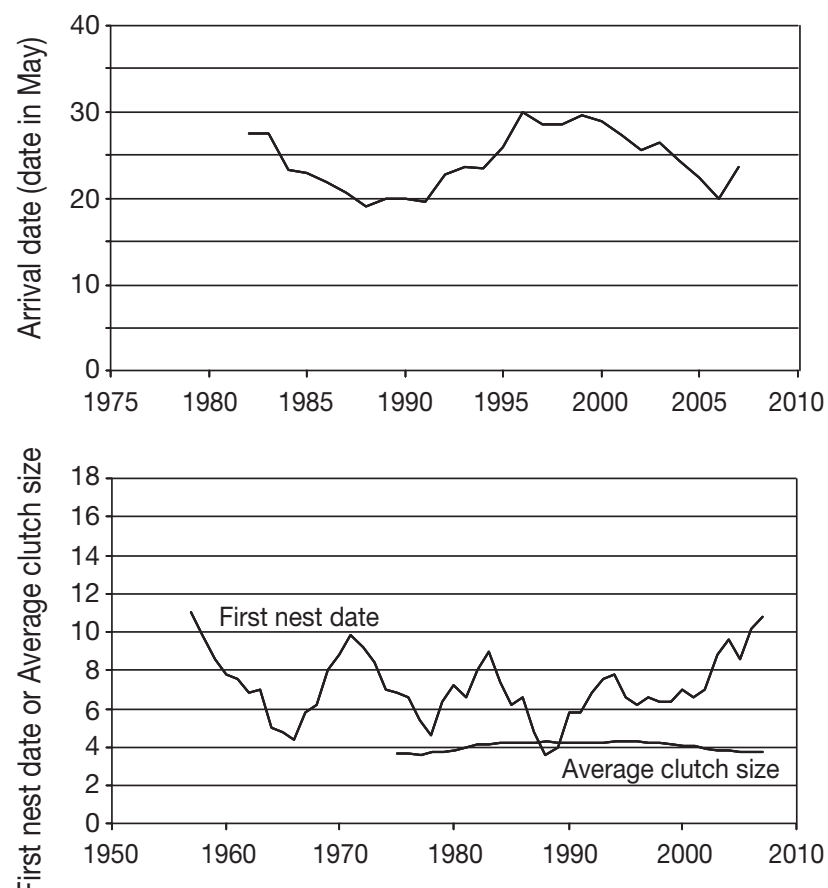

Fig. 2. Somateria mollissima. Arrival dates at Bíldsey (top) and first nest dates and average clutch sizes at Lækur (bottom) in northwest Iceland. Data are presented as 5 yr running means. Note different scales on both $x$ - and $y$-axes. Arrival date represents the date in May (1 May = 1) when half of all females have arrived, whereas first nest date represents the date $(1 \mathrm{May}=1)$ when the first nest was found differencing once. Stationarity was achieved for first nest dates and average clutch sizes by differencing once, and these hereafter differenced series are noted with a (1). First-order autoregressive models (AR-1) were used for subsequent analyses of breeding numbers(1), and average clutch size(1). A moving average model (MA 1,1) gave a better fit when analyzing first nest dates. Hence all analyses from Lækur are based on the differenced series, and variables shown represent annual changes in log-transformed breeding numbers, first nest dates, and average clutch sizes.

\section{RESULTS}

3.1. Were arrival, breeding numbers and clutch size related? Arrival date had no relationship with breeding numbers in Bíldsey $(t=1.60 ; \mathrm{p}=0.11)$. At Lækur, first nest date had no relationship with log-transformed breeding numbers(1) ( $t=0.56 ; \mathrm{p}=0.57$ ) and average clutch size had no relationship with log-transformed breeding numbers(1) ( $t=1.82 ; \mathrm{p}=0.07$ ) but was inversely related to first nest date(1) $(t=2.22, \mathrm{p}=0.026)$.

3.2. Annual variation in local weather conditions. For Bíldsey during the period 1978-2007, the first 2 PC scores (PC1, PC2) each explained $\geq 25 \%$ of the variation in local weather for all seasons (Table 2), while the third PC score for autumn explained $26 \%$ and was retained for model selection.

For Lækur during the period 1953-2007, the first 2 PC scores (PC1, PC2) each explained $\geq 25 \%$ of the variation in local weather for all seasons (Table 3 ). Thus, the first 2 PC scores were retained for analysis within all seasons.

3.3. Effects of summer weather conditions on eider breeding parameters. At Bíldsey, final ARIMA models for arrival date included a summer effect (summer-PC2, $t=2.29, \mathrm{p}=0.022$ ). Summer-PC2 indicates that a previous summer with high atmospheric pressure, accompanied by dry weather, had a negative effect on arrival dates (Fig. 3A), i.e. females arrived earlier following dry summers (summer-PC2 scores $>1.5$ ). Arrival date contained 2 potentially influential outliers (1995 and 1996; Fig. 3A), which may have been influenced by the re-settling of a pair of white-tailed sea eagles Haliaetus albicilla into the area, but the relationship was significant when the analysis was repeated without these values in the data set.

At Lækur, final ARIMA models for average clutch size included a negative effect of summer weather (summer-PC1, $t=2.15, \mathrm{p}=0.032$ ). Loadings of summerPC1 (Table 3) indicate that a wet previous summer with low pressures (PC scores $>1$ ) is likely to result in lower clutch sizes in the subsequent year. This effect is particularly due to the wet summers of 1988, 1994, 
Table 2. Loadings of principal components (PC) scores for weather variables from 1978-2007 at Bíldsey, Iceland. Loadings >0.5 or $<-0.5$ are in bold

\begin{tabular}{|c|c|c|c|c|c|c|c|c|c|}
\hline \multirow[b]{2}{*}{ Weather variables } & \multicolumn{2}{|c|}{ Summer } & \multicolumn{3}{|c|}{ Autumn } & \multicolumn{2}{|c|}{ Winter } & \multicolumn{2}{|c|}{ Spring } \\
\hline & PC1 & PC2 & PC1 & PC2 & PC3 & PC1 & PC2 & $\mathrm{PC} 1$ & PC2 \\
\hline Temperature $\left({ }^{\circ} \mathrm{C}\right)$ & 0.65 & 0.17 & 0.74 & -0.14 & 0.19 & 0.37 & 0.68 & 0.55 & -0.10 \\
\hline Precipitation (mm) & 0.41 & -0.56 & 0.54 & 0.63 & 0.12 & -0.35 & 0.71 & 0.60 & 0.11 \\
\hline Pressure (ppt) & -0.90 & 0.76 & -0.04 & -0.40 & 0.86 & 0.63 & -0.10 & -0.53 & -0.40 \\
\hline Wind speed $\left(\mathrm{m} \mathrm{s}^{-1}\right)$ & -0.64 & -0.29 & -0.39 & 0.66 & 0.45 & -0.58 & -0.10 & -0.24 & 0.90 \\
\hline $\begin{array}{l}\text { Percentage of variation explained } \\
\text { within each season }(\%)\end{array}$ & 39.1 & 31.1 & 35.1 & 28.1 & 26.1 & 45.8 & 33.3 & 43.9 & 24.9 \\
\hline
\end{tabular}

Table 3. Loadings of principal components (PC) scores for weather variables from 1953-2007 at Lækur, Iceland. Loadings >0.5 or $<-0.5$ are in bold

\begin{tabular}{|c|c|c|c|c|c|c|c|c|}
\hline \multirow[b]{2}{*}{ Weather variables } & \multicolumn{2}{|c|}{ Summer } & \multicolumn{2}{|c|}{ Autumn } & \multicolumn{2}{|c|}{ Winter } & \multicolumn{2}{|c|}{ Spring } \\
\hline & PC1 & PC2 & PC1 & PC2 & PC1 & PC2 & PC1 & $\mathrm{PC} 2$ \\
\hline Temperature $\left({ }^{\circ} \mathrm{C}\right)$ & 0.06 & 0.78 & 0.63 & -0.39 & -0.04 & 0.77 & 0.57 & 0.06 \\
\hline Precipitation (mm) & 0.66 & 0.25 & 0.66 & 0.30 & 0.52 & 0.49 & 0.59 & 0.27 \\
\hline Pressure (ppt) & -0.64 & 0.00 & -0.38 & -0.43 & -0.66 & 0.00 & -0.54 & 0.00 \\
\hline Wind speed $\left(\mathrm{m} \mathrm{s}^{-1}\right)$ & 0.38 & -0.58 & -0.15 & 0.75 & 0.54 & -0.41 & -0.20 & 0.96 \\
\hline$\%$ variation explained & 36.7 & 30.0 & 36.6 & 30.0 & 44.1 & 34.9 & 38.9 & 24.7 \\
\hline
\end{tabular}

1999, 2002 and 2006, all of which were followed by reductions in clutch size in the following breeding seasons. Furthermore, no wet (PC scores > 1) summers were followed by increased clutch sizes (Fig. 3B).

3.4. Effects of autumn weather conditions on eider breeding parameters. At Lækur, final ARIMA models for average clutch size included a negative effect of the previous year's autumn weather (autumn-PC1, $t=2.02$, $\mathrm{p}=0.044$ ). Loadings of autumn-PC1 (Table 3 ) indicate that a relatively warm, wet autumn likely resulted in lower clutch sizes in the following breeding season (Fig. 4).

3.5. Effects of winter weather conditions on eider breeding parameters. At Bíldsey, final ARIMA and regression models for residual breeding numbers included a winter effect (winter-PC2, $t=2.50, \mathrm{p}=$ 0.012 ), indicating that wet and warm winters (Table 2) were likely to be followed by an increase in numbers of breeding birds (Fig. 5A).

At Lækur, final ARIMA models for first nest date indicated that a wet, windy winter with low pressures were likely to be followed by later first nest dates (winter-PC1, $t=2.37, \mathrm{p}=0.018$; Fig. 5B, Table 3).

3.6. Effects of spring weather conditions on eider breeding parameters-. At Bíldsey, final ARIMA models for arrival date indicated that arrival was earlier in windier springs (spring-PC2, $t=29.02, \mathrm{p}>0.0001$; Fig. 6A). Arrival date contained 2 potentially influen-
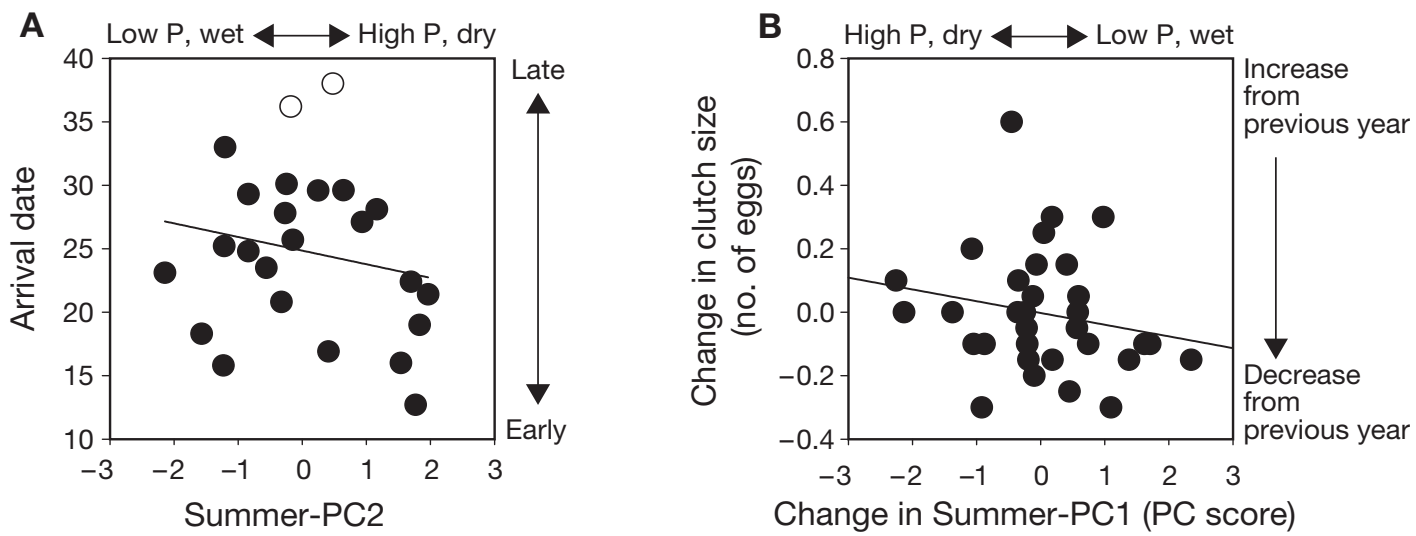

Fig. 3. Somateria mollissima. Effects of summer weather on annual changes in common eider arrival dates on Bíldsey (A) and average clutch sizes at Lækur (B), northwest Iceland. P: atmospheric pressure. (A) Open circles indicate only 1995 and 1996 , which may have been influenced by the re-settling of a pair of white-tailed sea eagles near Bíldsey; arrival date: 1 May = 1 .

(B) Change refers to change from previous year; P: atmosphere pressure 


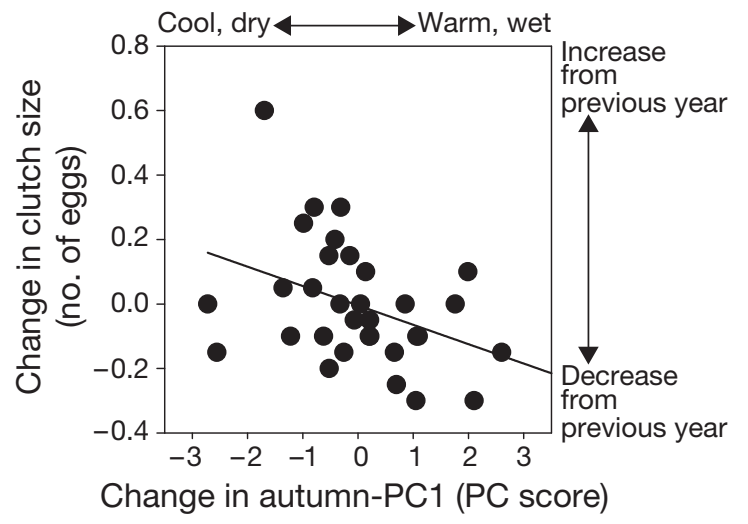

Fig. 4. Somateria mollissima. Effects of autumn weather on annual changes in average clutch size of common eiders at Lækur, northwest Iceland. Change refers to change from previous year

tial outliers (1995 and 1996; Fig. 6A), which may have been influenced by the re-settling of a pair of whitetailed sea eagles into the area, but this relationship was significant when the analysis was performed without these values in the data set.

At Lækur, final ARIMA models for average clutch size indicated that a warm, wet spring with low pressure had a positive effect on clutch size (spring-PC1, $\mathrm{t}=2.37, \mathrm{p}=0.018$; Fig. 6B).

3.7. Regional-scale NAO index and eider breeding parameters. The midwinter NAO index was positively correlated with winter-PC1 for the period 1953-2007 $(t=11.63, \mathrm{p}=0.0001)$ but had no relationship with other local weather indices. Positive NAO values were associated with wet, windy winters and low pressures.

In Bíldsey, ARIMA and regression models indicated that there was no relationship between the midwinter NAO index and breeding numbers $(t=0.28, \mathrm{p}=0.78)$ or arrival date $(t=0.09, \mathrm{p}=0.93)$.

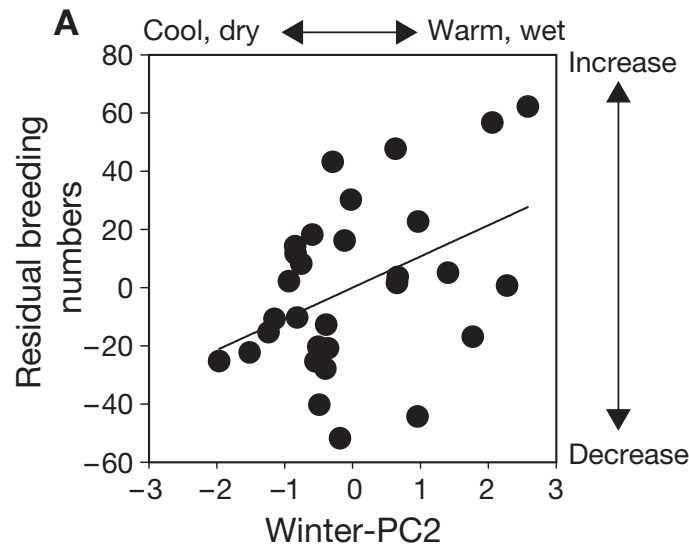

At Lækur, ARIMA and regression models indicated that there was no relationship between the midwinter NAO index and breeding numbers $(t=0.59, \mathrm{p}=0.59)$ or clutch size $(t=0.63, \mathrm{p}=0.53)$. However, there was a positive relationship between the midwinter NAO index and arrival date $(t=2.45, \mathrm{p}=0.014)$; a negative midwinter NAO index advanced the arrival of breeding females at Lækur (Fig. 7).

3.8. Summary of findings. In summary, we found that (1) breeding numbers were correlated with the degree of warmness of winters; (2) arrival dates/first nest dates were correlated with wetness and wind speeds of the previous summer, winter and spring; (3) clutch size was correlated with warmness and wetness of the previous summer, autumn and spring; (4) the NAO index was positively correlated with first nest date (Table 4 ).

\section{DISCUSSION}

4.1. Long-term population stability of eiders in Iceland. Counts of eiders at Bíldsey between 1978 and 2007 were characterised by an overall weak positive trend with peaks and lows (Fig. 1), while counts in Lækur were characterised by a steady upward trend in 1953-1990, followed by a period of stability in 19902000 and then a sharp decline in 2000-2007 (Fig. 1). These trends may not be typical of many other colonies since declining protective efforts, due to human resettlement, have caused a decline in breeding numbers within some colonies (Jónsson 2001). Overall, population trends in the 2 colonies studied are probably best explained by farmer effort; the population was stable at Bíldsey but farmer effort may have driven the local population to the site-specific carrying capacity at Lækur. The decline at Lækur in 1999-2007 seems to be

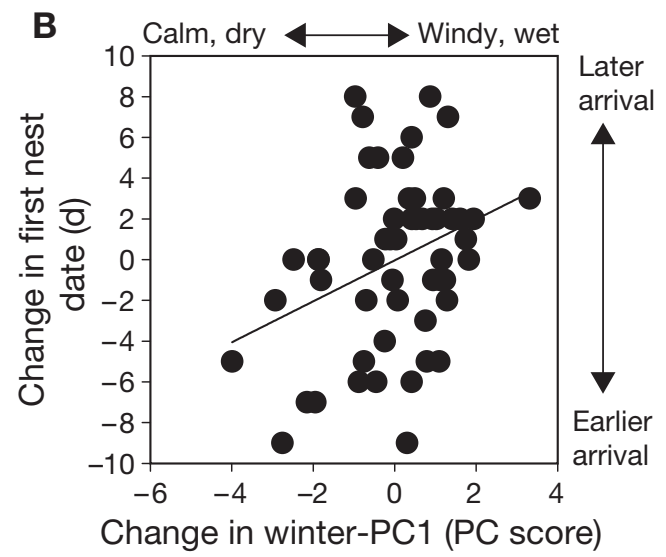

Fig. 5. Somateria mollissima. Effects of winter weather on annual changes in numbers of breeding common eiders on Bíldsey (A) and dates of first nest initiation at Lækur (B), northwest Iceland. Change refers to change from previous year 
A

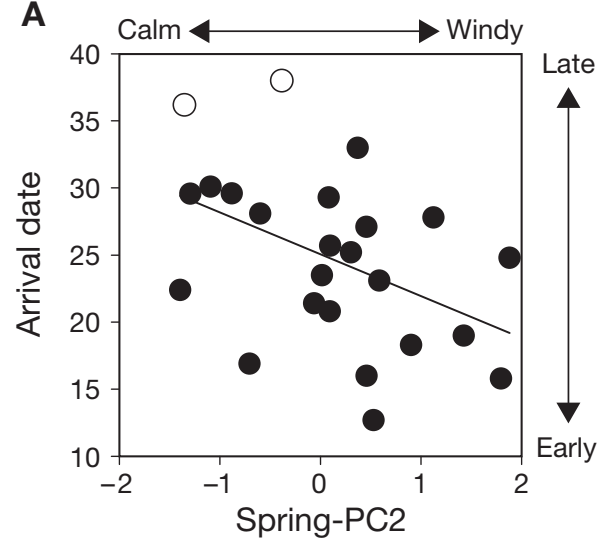

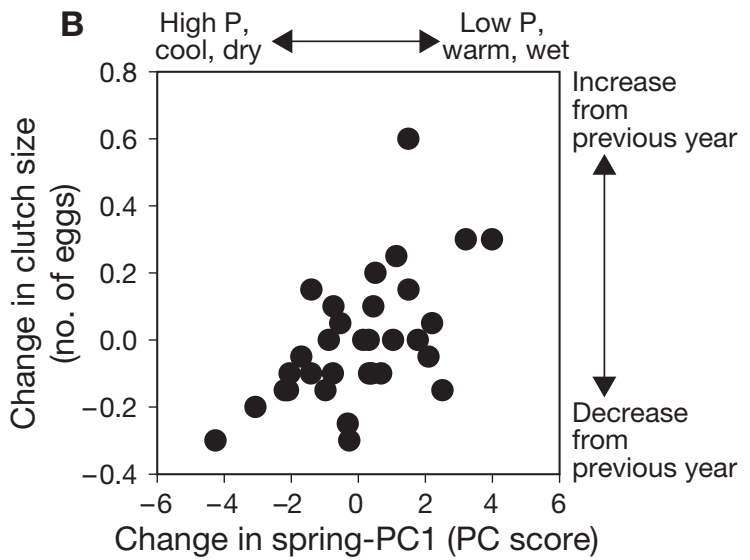

Fig. 6. Somateria mollissima. Effects of spring weather on annual changes in common eider arrival dates in Bíldsey (A) and average clutch sizes at Lækur (B), northwest Iceland. (A) Arrival date: 1 May $=1$. Open circles indicate years which were treated as influential outliers (see text for details). (B) P: atmospheric pressure; change refers to change from previous year

correlated with a decreased clutch size (from $\geq 4.1$ in 1990-1997 to 3.85 in 2005-2007) during this period, indicating a probable decline in the condition of nesting females.

4.2. Is there evidence for limited effects of the NAO index on the common eider? The NAO index is related to either population size or timing of migration or breeding in many bird populations (e.g. Gunnarsson et al. 2006, Lehikoinen et al. 2006, Robinson et al. 2007) . However, local weather is often a better predictor of bird phenology in certain areas, especially for populations that travel relatively short distances between winter and breeding areas (Robinson et al. 2007, Husek \& Adamík 2008). Our findings indicate that the NAO index has limited effects on the breeding ecology of the common eider and that the effects of local weather events are more marked. However, largescale climate systems often relate to populations via their effects on local weather conditions (Anders \& Post

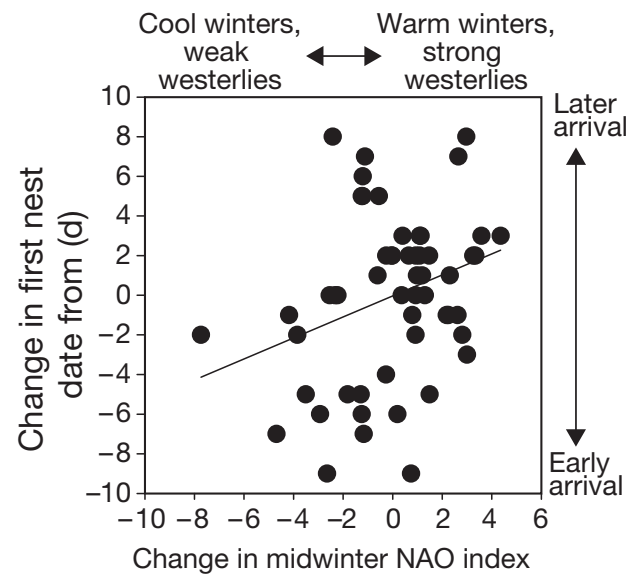

Fig. 7. Relationship between the mid-winter NAO index and annual changes in first nest initiation dates at Lækur, Iceland. Change refers to change from previous year
2006) and we indeed found a positive correlation between the midwinter NAO index and winter-PC1 (indicating a NAO influence on the interplay among precipitation, wind and air pressure). We fully expect the NAO index to be of utility for studies of many other migratory bird populations in Iceland, most of which winter in western Europe and are thus exposed to climatic conditions on a larger geographic scale, for which the NAO index is more suitable (Gunnarsson et al. 2006).

4.3. Causes of the relationships between winter conditions and numbers of breeders. The significant effect of winter weather conditions on breeding numbers at Bíldsey suggests that more females are unable to fatten properly during colder winters and later return to the colony. In fact, the sudden drops in breeding numbers, which then recover the following year, may indicate a decision for non-breeding, which is common in this species, where as many as 10 to $30 \%$ of all females may decide to skip breeding during a given year (Coulson 1984). The females may simply fail to reach the threshold levels of endogenous reserves necessary for egg formation or sustenance during incubation. A cold winter may require increased use of endogenous reserves for survival (Systad et al. 2000).

Pair formation may be delayed in cold winters or perhaps initiated late following wet autumn seasons. Females may pair later in cold winters or cold climates (Raitasuo 1963, Jónsson \& Gardarsson 2001). Furthermore, low body mass in winter delays the onset of pair formation (Pattenden \& Boag 1989), thus delaying the attainment of the higher social status of paired females, which is critical for the deposition of endogenous reserves (Ashcroft 1976, Hepp 1984). Pair formation begins during autumn but plateaus during midwinter and then resumes during spring (Spurr \& Milne 1976). This mid-winter break is further indicated by 
Table 4. Somateria mollissima. Summary results of weather analysis for common eider nesting on Bíldsey and at Lækur in Iceland. P: atmospheric pressure; NAO: North Atlantic oscillation. Blanks: no relationship

\begin{tabular}{|c|c|c|c|c|}
\hline & \multicolumn{2}{|c|}{ _ Bíldsey } & \multicolumn{2}{|c|}{$L_{-}$Lækur } \\
\hline & $\begin{array}{l}\text { Breeding } \\
\text { numbers }\end{array}$ & $\begin{array}{l}\text { Arrival } \\
\text { date }\end{array}$ & $\begin{array}{l}\text { First nest } \\
\text { date }\end{array}$ & $\begin{array}{l}\text { Clutch } \\
\text { size }\end{array}$ \\
\hline $\begin{array}{l}\text { Previous } \\
\text { summer }\end{array}$ & & $\begin{array}{l}\text { Dry + high P: } \\
\text { advanced }\end{array}$ & & $\begin{array}{l}\text { Wet }+ \text { low } P \text { : } \\
\text { reduced }\end{array}$ \\
\hline $\begin{array}{l}\text { Previous } \\
\text { autumn }\end{array}$ & & & & $\begin{array}{l}\text { Warm + wet: } \\
\text { reduced }\end{array}$ \\
\hline Winter & $\begin{array}{l}\text { Warm, wet: } \\
\text { increased }\end{array}$ & & $\begin{array}{c}\text { Wet + windy } \\
\text { + low P: } \\
\text { delayed }\end{array}$ & \\
\hline Spring & & $\begin{array}{l}\text { Windy: } \\
\text { advanced }\end{array}$ & & $\begin{array}{c}\text { Warm + wet } \\
\text { + low P: } \\
\text { higher }\end{array}$ \\
\hline $\begin{array}{l}\text { Midwinter } \\
\text { NAO }\end{array}$ & & & $\begin{array}{l}\text { Negative: } \\
\text { advanced }\end{array}$ & \\
\hline
\end{tabular}

sible implications for breeding success. Arrival and breeding numbers were unrelated in both colonies, which suggest that, over these ranges of population size, delayed breeding (or even deferred breeding) was unrelated to population size in the present or previous years. Common eider in Iceland is relatively more sedentary than most other waterfowl; thus, arrival date may not always predict nest initiation date, particularly if females arriving early (i.e. those in better condition) have a longer pre-laying period and nest earlier independent of arrival date (Bêty et al. 2003).

Females arrived earlier in Bíldsey following windy springs but no such pattern was suggested at Lækur. We suspect that such an early arrival in Bíldsey does not mean earlier nest initiation because we used the date when $50 \%$ of all birds had

decreased time spent by males in social displays, which increases as daylength increases again in spring (Systad et al. 2000). It is possible that this decreased social activity represents an adaptation for energy conservation during the coldest parts of the year, when inclement weather is also most likely.

Severe winters may not only affect the numbers of breeding females but also of predators (Drever \& Clark 2007), which can cause breeding numbers to drop within years of high predator abundance (Jónsson 2001). However, the winter effect at Bíldsey was mostly due to warm winters yielding higher numbers of breeding birds whereas the outcome was variable for harsher winters. We suspect that in years when common eiders sufferred mortality due to cold and subsequent starvation, predators such as gulls (Larus spp.) or ravens (Corvus corax) probably also sufferred such losses. Furthermore, warmer winters may also benefit alternative prey for these predators, relieving some of the predation pressure on common eider females.

4.4. Effects of weather conditions on arrival dates. In considering relationships between weather and arrival, we assumed that early arrival reflected a relatively good body condition in the studied population. Our analysis indicates that arrival of eiders at the breeding colony is (1) advanced in windy springs (spring temperature and precipitation seem to have no effect in Bíldsey); and (2) delayed in winters dominated by low pressure systems or by higher NAO values than in the previous year (Lækur). We also found some evidence that conditions during the previous summer affect arrival of females in the following breeding season. Thus, weather conditions throughout the preceding year can influence arrival dates of eiders, with pos- arrived. In contrast, we used first nest date at Lækur, where there was no effect of wind on arrival date. We speculate that windy conditions in spring may either interfere with foraging or facilitate it in shallow intertidal zones if increased wave action washes prey into such areas. In east Breiðafjörður, such wave action may be prominent because of the numerous islands that form a network of breaking points (a mixing zone) for the flow of seawater.

The breeding strategy of females may also be influenced by events during the previous summer, particularly food conditions at breeding grounds (Gardarsson \& Einarsson 1997). Gull predation on eider ducklings was $2.5 \times$ higher in rainy, windy weather than in calm weather on the Ythan estuary in Scotland (Mendenhall \& Milne 1985). Traylor \& Alisauskas (2006) found evidence of increased survival of broods of another seaduck, the white-winged scoter Melanitta fusca deglandi during warm, dry, and calm conditions, relative to that during cool, wet and windy conditions. Weather during the previous summer is a somewhat indirect determinant of breeding success but at least represents a large part of the conditions experienced during the preceding breeding season.

It is possible that females are more prone to skip a breeding season following a dry summer (summer-PC2 at Bíldsey), and warm summers seem to be followed by numbers that remain stable in the following year (summer-PC2 at Lækur). However, the decision to skip might be expected to be more likely following an unfavourable summer rather than a favourable one. In geese, individuals that breed successfully in season $t$ are more likely than others to return with a brood in season $t+1$ (Black \& Owen 1989), suggesting that favourable conditions encourage breeding in the subsequent season. 
Temperature effects on duck nests may include direct effects on the birds themselves via nest initiation date, or indirect via invertebrate food supply, or predator activity. However, spring temperature had no effects on arrival/first nest date in this study (springPC1), although wind affected arrival at Bíldsey in the calmest and windiest of years. However, extremely favourable or unfavourable spring seasons can have marked effects on clutch size (Fig. 6B). Such a finding should be expected for a species with a wide distribution range such as the common eider.

4.5. Effects of weather conditions on clutch sizes. We found a negative relationship between first nest date and clutch size. Conversely, Erikstad et al. (1993) found no relationship between clutch size and laying date in the common eider during $4 \mathrm{yr}$ of nesting in Norway. Individual females can vary their clutch size between adjacent seasons (up to \pm 3 eggs) and this variation was positively related to their body mass at hatching and the subsequent care given to broods (Erikstad et al. 1993). Thus, condition and clutch size are linked in this species, which suggests that weather effects on clutch size operate via body condition.

Common eiders have a brood amalgamation strategy (crèching), where some females cooperate with brood rearing while others abandon their broods (Bustnes \& Erikstad 1991, Erikstad et al. 1993, Öst et al. 2002). Clutch size is related to the subsequent brood rearing strategy and a trade-off has been suggested between body reserve allocation and clutch size, incubation and brood care. We propose that unfavourable weather conditions (via their effects on body condition) during autumn/winter/spring may subsequently influence the resulting clutch size. Tending and abandoning broods are not individually fixed strategies but change between years within individuals (Bustnes \& Erikstad 1991). Weather effects on females during brood rearing may in turn influence any relationship between summer weather and breeding numbers or arrival in the following year.

\section{CONCLUSION}

In the common eider, arrival date seems to be independent of breeding numbers but both variables are related to weather events. Weather effects are probably dependent on colony location and associated attributes operating at different scales, such as migration distances, bathymetry, shelter from prevailing winds etc. Further studies of this population will address inter-colony differences in the variables studied here. Since Iceland is not the coldest part of the common eider distribution range, we suspect that weather effects on the common eider are mostly indi- rect (i.e. via food and habitat availability) rather than direct (i.e. affecting the health of the adult common eiders themselves). However, direct effects of weather on duckling survival have been reported for other species (Traylor \& Alisauskas 2006).

In some of our analyses, a significant weather effect was produced by similar responses in 5 to $10 \mathrm{yr}$ with certain conditions which could be characterised as 'unusual'. Examples are the possible effects of (1) delayed arrival date following wet, windy winters at Lækur (Fig. 5B) and (2) decreased clutch size in the subsequent spring following particularly wet summers (Fig. 3B). A relevant question is whether such unusual conditions could become more common following future climate changes and redistribution of depressions or other weather variables.

We found that arrival and clutch size were more likely to be affected by weather than are breeding numbers. Unfavourable conditions during autumn, winter and spring may interfere with accumulation of body reserves which sustain the females during breeding and into brood rearing. These findings suggest that unfavourable changes in the distribution and frequencies of depressions within each season could affect future breeding numbers of this species.

Acknowledgements. We thank Á. Bjartmars and Z. F. Porvaldssson for giving us access to their eider data. B. Pórisson and U. K. Pétursdóttir ass isted with contacting eiderdown farmers. T. Jónsson at the Icelandic Meteorological Office provided the relevant climate data. This study was funded by project grants from the Icelandic Research Counsel (RANNÍS), the Agricultural Productivity Fund and the Icelandic Eiderdown-farmers Association.

\section{LITERATURE CITED}

Alisauskas RT (2002) Arctic climate, spring nutrition, and recruitment in midcontinent lesser snow geese. J Wildl Manage 56:43-54

$>$ Anders AD, Post E (2006) Distribution-wide effects of climate on population densities of a declining migratory landbird. J Anim Ecol 75:221-227

Ankney CD, MacInnes CD (1978) Nutrient reserves and reproductive performance of female lesser snow geese. Auk 95:459-471

Anteau MJ, Afton AD (2006) Diet shifts of lesser scaup are consistent with the spring condition hypothesis. Can J Zool 84:779-786

Arnold JM, Hatch JJ, Nisbet ICT (2004) Seasonal declines in reproductive success of the common tern Sterna hirundo: timing or parental quality? J Avian Biol 35:33-45

Arzel C, Elmberg J, Guillemain M (2006) Ecology of springmigrating Anatidae: a review. J Ornithol 147:167-184

Asbirk S, Berg L, Hardeng G, Koskimies P, Petersen A (1997) Population sizes and trends of birds in the Nordic countries 1978-1994. TemaNord 614, Nordic Council of Ministers, Copenhagen

Ashcroft RE (1976) A function of the pairbond in the common eider. Wildfowl 27:101-105 
Bédard J, Nadeau A, Giroux JF, Savard JP (2008) Eiderdown: characteristics and harvesting procedures. Société Duvetnor Ltée and Canadian Wildlife Service, Environment Canada, Quebec

Bêty J, Gauthier G, Giroux JF (2003) Body condition, migration, and timing of reproduction in snow geese: a test of the condition-dependent model of optimal clutch size. Am Nat 162:110-121

Bêty J, Giroux JF, Gauthier G (2004) Individual variation in timing of migration: causes and reproductive consequences in greater snow geese Anser caerulescens caerulescens. Behav Ecol Sociobiol 57:1-8

Both C, Bouwhuis S, Lessels CM, Visser ME (2006) Climate change and population declines in a long-distance migratory bird. Nature 441:81-83

Brocklebank JC, Dickey DA (2003) SAS for forecasting time series, 2nd edn. SAS Institute, Cary, NC

Bustnes JO, Erikstad KE (1991) The role of failed nesters and brood abandoning females in the creching system of the common eider Somateria mollissima. Ornis Scand 22: 335-339

Bustnes JO, Erikstad KE, Bjorn TH (2002) Body condition and brood abandonment in common eiders breeding in the high Arctic. Waterbirds 25:63-66

Coulson JC (1984) The population dynamics of the eider duck Somateria mollissima and evidence of extensive nonbreeding by adult ducks. Ibis 126:525-543

Drent RJ, Fox AD, Stahl J (2006) Travelling to breed. J Ornithol 147:122-134

- Drever MC, Clark RG (2007) Spring temperature, clutch initiation date and duck nest success: a test of the mismatch hypothesis. J Anim Ecol 76:139-148

Durant JM, Anker-Nilssen T, Hjermann DO, Stenseth NC (2004) Regime shifts in the breeding of an Atlantic puffin population. Ecol Lett 7:388-394

Erikstad KE, Bustnes JO, Moum T (1993) Clutch-size determination in precocial birds: a study of the common eider. Auk 110:623-628

> Frederiksen M, Harris MP, Daunt F, Rothery P, Wanless S (2004) Scale-dependent climate signals drive breeding phenology of three seabird species. Glob Change Biol 10: 1214-1221

Gardarsson A, Einarsson A (1997) Numbers and production of Eurasian wigeon in relation to conditions in a breeding area, Lake Myvatn, Iceland. J Anim Ecol 66:439-451

Goudie RI, Robertson GJ, Reed A (2000) Common eider Somateria mollissima. In: Poole A, Gill F (eds) The birds of North America, No. 546. The Birds of North America, Philadelphia, PA

Gunnarsson TG, Gill JA, Sigurbjörnsson P, Sutherland WJ (2004) Arrival synchrony in migratory birds. Nature 431: 646

Gunnarsson TG, Gill JA, Atkinson PW, Gélinaud G and others (2006) Population-scale drivers of individual arrival times in migratory birds. J Anim Ecol 75:1119-1127

Hamilton DJ (2001) Feeding behaviour of common eider ducklings in relation to availability of rockweed habitat and duckling age. Waterbirds 24:233-241

Hepp GR (1984) Dominance in wintering Anatinae: potential effects on clutch size and time of nesting. Wildfowl 35: 132-134

> Hurrell JW, Kushnir Y, Visbeck M (2001) The North Atlantic oscillation. Science 291:603-605

> Husek J, Adamík P (2008) Long-term trends in the timing of breeding and brood size in the red-backed shrike Lanius collurio in the Czech Republic, 1964-2004. J Ornithol 149: 97-103
IPCC (2001) Climate change 2001: synthesis report. In: Watson RT \& the Core Writing Team (eds) Contribution of Working Groups I, II, and III to the third assessment report of the Intergovernmental Panel on Climate Change. Cambridge University Press, Cambridge, p 398

Jónsson J (2001) Æðarfugl og æðarrækt á Íslandi (Common eider and eider husbandry in Iceland). Æðarræktarfélag Íslands, Reykjavík. Mál og Mynd, Reykjavík (in Icelandic)

Jónsson T (2006) Hitafar á Íslandi eftir 1800 (Temperatures in Iceland from 1800). Icelandic climate. The Icelandic Meteorological Office, available at www.vedur.is/loftslag/ breytingar/fra1800/hitafar/ (in Icelandic)

Jónsson JE, Gardarsson A (2001) Pair formation in relation to climate: mallard, Eurasian wigeon and Eurasian teal in Iceland. Wildfowl 52:55-68

Jónsson JE, Afton AD, Alisauskas RT, Bluhm CK, El Halawani ME (2006) Ecological and physiological factors affecting brood patch area and prolactin levels in arctic-nesting geese. Auk 123:405-418

Jonzen N, Linden A, Ergon T, Knudsen E and others (2006) Rapid advance of spring arrival dates in long-distance migratory birds. Science 312:1959-1961

> Lehikoinen A, Kilpi M, Öst M (2006) Winter climate affects subsequent breeding success of common eiders. Glob Change Biol 12:1355-1365

Lovvorn JR (1994) Nutrient reserves, probability of cold spells and the question of reserve regulation in wintering canvasbacks. J Anim Ecol 63:11-23

McKinney F (1986) Ecological factors influencing the social systems of migratory dabbling ducks. In: Rubenstein DI, Wrangham RW (eds) Ecological aspects of social evolution. Princeton University Press, Princeton, NJ, p 73-82

Meijer T, Drent R (1999) Re-examination of the capital and income dichotomy in breeding birds. Ibis 141:399-414

Mendenhall VM, Milne H (1985) Factors affecting duckling survival of eiders Somateria mollissima in northeast Scotland. Ibis 127:148-158

> Newton I (2006) Can conditions experienced during migration limit the population levels of birds? J Ornithol 147: $146-166$

> Newton I (2007) Weather-related mass-mortality events in migrants. Ibis 149:453-467

Novoa C, Besnard A, Brenot JF, Ellison LN (2008) Effect of weather on the reproductive rate of rock ptarmigan Lagopus muta in the eastern Pyrenees. Ibis 150:270-278

Olsson EGA, Thorvaldsen P (2006) The eider conservation paradox in Tautra - a new contribution to the multidimensionality of the agricultural landscapes in Europe. Environ Sci Policy 9:343-349

Owen M, Black JM (1989) Factors affecting the survival of barnacle geese on migration from the breeding grounds. J Anim Ecol 58:603-617

Öst M, Mantila L, Kilpi M (2002) Shared care provides timebudgeting advantages for female eiders. Anim Behav 64: 223-231

Öst M, Smith BD, Kilpi M (2008) Social and maternal factors affecting duckling survival in eiders Somateria mollissima. J Anim Ecol 77:315-325

Parker H, Holm H (1990) Patterns of nutrient and energy expenditure in female common eider nesting in the high Arctic. Auk 107:660-668

Parmesan C, Yohe G (2003) A globally coherent fingerprint of climate change impacts across natural systems. Nature 421:37-42

Pattenden RK, Boag DA (1989) Effects of body mass on courtship, pairing, and reproduction in captive mallards. Can J Zool 67:495-501 
Petersen Æ, Skírnisson K (2001) Lifnaðarhættir æðarfugla á Íslandi (Common eider in Iceland). In: Jónsson J (ed) Æðarfugl og æðarrækt á Íslandi (Common eider breeding in Iceland). Mál og Mynd, Reykjavík, p 13-46

Poussart C, Larochelle J, Gauthier G (2000) The thermal regime of eggs during laying and incubation in greater snow geese. Condor 102:292-300

Prop J, Black JM, Shimmings P (2003) Travel schedules to the high arctic: barnacle geese trade-off the timing of migration with accumulation of fat deposits. Oikos 103: 403-414

Raitasuo K (1963) Social behavior of the mallard Anas platyrhynchos in the course of the annual cycle. Finn Game Res $24: 1-71$

Robinson RA, Baille SM, Crick HQP (2007) Weather-dependent survival: implications of climate change for passerine population processes. Ibis 149:357-364

Sæther BE, Sutherland WJ, Engen S 2004. Climate influences on avian population dynamics. In: Møller AP, Berthold P, Fiedler W (eds) Advances in ecological research: birds and climate change 35, Elsevier, Amsterdam, p 185-209

SAS Institute (2001) SAS/SYSTAT user's guide, version 8. SAS Institute, Cary, NC

Serreze MC, Walsh JE, Chapin FS, Osterkamp T and others (2000) Observational evidence of recent change in the northern high-latitude environment. Clim Change 46: 159-207

Skírnisson K, Jónsson AA, Sigfússon AP, Sigurðarson S (1996)

Editorial responsibility: Mauricio Lima,

Santiago, Chile
Seasonal changes of the food composition and condition of the common eider in Iceland. Bull Scand Soc Parasitol 6: $127-128$

> Solonen T (2008) Large-scale climatic phenomena and timing of breeding in a local population of the osprey Pandion haliaetus in southern Finland. J Ornithol 149:229-235

Sparks TH, Bairlein F, Bojarinova JG, Hüppop O and others (2005) Examining the total arrival distribution of migratory birds. Glob Change Biol 11:22-30

Spurr E, Milne H (1976) Adaptive significance of autumn pair formation in the common eider Somateria mollissima (L). Ornis Scand 7:85-89

Stefánsson RA, von Schmalensee M, Skarphéðinsson KH (eds) (2008) Research and monitoring of the Breiðafjörður Bay, West-Iceland (Rannsóknir og vöktun á náttúru Breiðafjarðar). Workshop report, 12 to 13 Sept 2007, Stykkishólmur, Iceland [in Icelandic]

Systad GH, Bustnes JO, Erikstad KE (2000) Behavioral responses to decreasing day length in wintering sea ducks. Auk 117:33-40

Thomas CD, Cameron A, Green RE, Bakkenes M and others (2004) Extinction risk from climate change. Nature 427: $145-148$

Traylor JJ, Alisauskas RT (2006) Effects of intrinsic and extrinsic factors on survival of white-winged scoter Melanitta fusca deglandi ducklings. Auk 123:67-81

Yaffee R (2000) Introduction to time-series analysis and forecasting. Academic Press, Amsterdam

Submitted: June 23, 2008; Accepted: January 5, 2009

Proofs received from author(s): March 17, 2009 